A PRELIMINARY SEISMICITY STUDY OF THE SOUTHERN NEVADA REGION FOR THE MONTH OF AUGUST 1972 


\section{DISCLAIMER}

This report was prepared as an account of work sponsored by an agency of the United States Government. Neither the United States Government nor any agency Thereof, nor any of their employees, makes any warranty, express or implied, or assumes any legal liability or responsibility for the accuracy, completeness, or usefulness of any information, apparatus, product, or process disclosed, or represents that its use would not infringe privately owned rights. Reference herein to any specific commercial product, process, or service by trade name, trademark, manufacturer, or otherwise does not necessarily constitute or imply its endorsement, recommendation, or favoring by the United States Government or any agency thereof. The views and opinions of authors expressed herein do not necessarily state or reflect those of the United States Government or any agency thereof. 


\section{DISCLAIMER}

Portions of this document may be illegible in electronic image products. Images are produced from the best available original document. 


\section{LEGAL NOTICE}

This report was prepared as an account of work sponsored by the United States Government. Neither the United States nor the United States Atomic Energy Commission, nor any of their employees, nor any of their contractors, subcontractors, or their employees, makes any warranty, express or implied, or assumes any legal liability or responsibility for the accuracy, comple teness or usefulness of any information, apparatus, product or process disclosed, or represents that its use would not infringe privatelyowned rights.

Available From The

National Technical Information Service

U. S. Department of Commerce

Springfield, Virginia 22151 


\section{A PRELIMINARY SEISMICITY STUDY OF THE SOUTHERN NEVADA REGION}

FOR THE MONTH OF AUGUST 1972

KENNETH C. BAYER

KENNETH W. KING

OCTOBER 1972

PREPARED FOR THE U.S. ATOMIC ENERGY COMMISSION

NEVAD $\Lambda$ OPERATIONS OFFICE

UNDER CONTRACT AT(29-2)-746 


\section{THIS PAGE \\ WAS INTENTIONALLY \\ LEFT BLANK}




\section{TABLE OF CONTENTS}

Page

$\begin{array}{ll}\text { ABSTRACT } & 1\end{array}$

1. INTRODUCTION 1

2. DISCUSSION 4

3. GENERAL SEISMICITY 5

4. ACKNOWLEDGMENTS 9

5. REFERENCES 9

APPENDIX - Hypocenter Summary $\quad A-1$

TABLE 1 - Seismic Station Constants 3

FIGURES

1. Station Location Map 2

2. Earthquakes in the Southern Nevada Region for the Month 6 of August 1972

3. Earthquakes on the Nevada Test Site for the Month of 7 August 1972 


\title{
A PRELIMINARY SEISMICITY STUDY OF THE SOUTHERN NEVADA REGION FOR THE MONTH OF AUGUST 1972
}

\author{
Kenneth C. Bayer \\ Kenneth W. King
}

\begin{abstract}
A cooperative (ESL, Sandia Laboratories, USGS) network of 21 seismic velocity sensitive stations is operated in the southern Nevada area; the stations are monitored by the NOAA/ESL Nevada Special Projects Party located in Las Vegas, Nevada.

There was no significant earthquake pattern that developed during the month of August 1972. Two seismicity maps are included; one of the southern Nevada region and the second of the seismicity on the Nevada Test Site (NTS).

This is the second in a series of monthly seismic bulletins covering the southern Nevada region, monitored by the Las Vegas, Nevada-based Special Projects Party. The output is listed in the Hypocenter Summary. The listing is the result of data scaled only from the local cooperative network, and solutions determined by a local epicenter program. A total of 7.0 epicenters is listed.
\end{abstract}

\section{INTRODUCTION}

This report contains a summary of earthquakes recorded by a network of 19 seismograph stations in the southern Nevada region, and 2 stations in central Nevada, for the month of August 1972. This is the second in a series of monthly seismicity reports, Bayer (1972), embracing southern Nevada and the border zones of Arizona, California, and Utah

The southern Nevada seismic network station locations are shown in figure 1. All stations are located in Nevada with the exception of Leeds (LEE) in Utah, and Darwin (DAC) in California. This net is operated by the three cooperating agencies listed in table 1. The data from all of the stations are recorded on $16 \mathrm{~mm}$ film and magnetic tape by the Nevada Special Projects Party (NSPP) of the National Oceanic and Atmospheric 


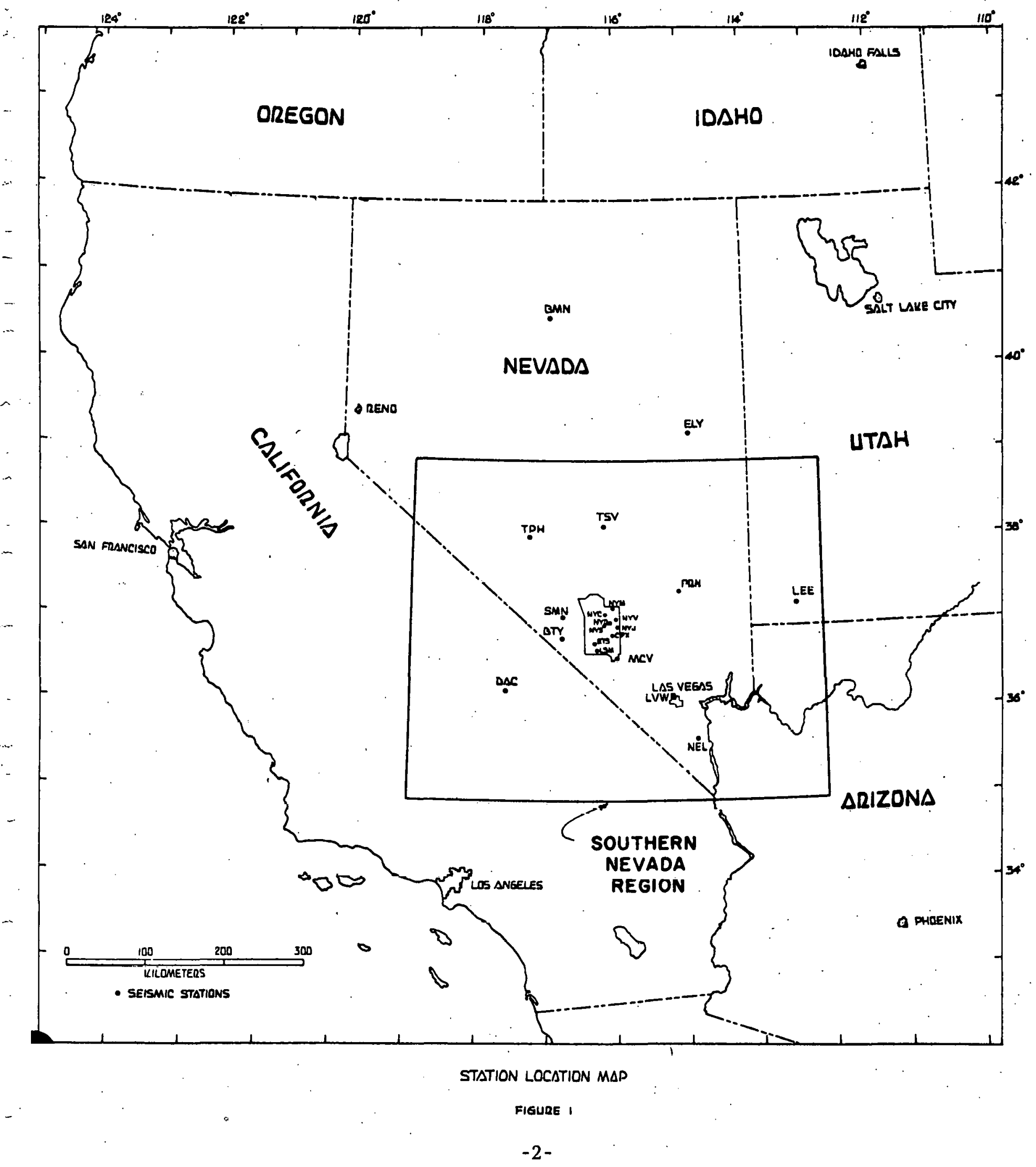


TABLE I

SEISMIC STATION CONSTANTS

\begin{tabular}{|c|c|c|c|c|c|c|}
\hline & $\begin{array}{l}\text { * Station } \\
\text { Name }\end{array}$ & $\begin{array}{l}\text { Latitude } \\
\text { ( North) }\end{array}$ & $\begin{array}{l}\text { Longitude } \\
\text { (West) }\end{array}$ & $\begin{array}{c}\text { Elev. } \\
\text { (Meters) }\end{array}$ & $\begin{array}{l}\text { Inst. } \\
\text { Comp. }\end{array}$ & $\begin{array}{l}\text { Approx. Magni- } \\
\text { fication @ } 1 \mathrm{~Hz}\end{array}$ \\
\hline
\end{tabular}

NOAA/ESL/NEVADA SEISMOGRAPH STATIONS

$\begin{array}{lllllll}\text { BTY } & \text { Beatty } & 36^{\circ} 53.63^{\prime} & 116^{\circ} 45.88^{\prime} & 1008 & \text { SPZ } & 100 \mathrm{~K} \\ \text { CPX } & \text { CP-1 (Control Point \#1) } & 36^{\circ} 55.92^{\prime} & 116^{\circ} 03.33^{\prime} & 1285 & \text { SPZ } & 110 \mathrm{~K} \\ \text { ETS } & \text { Engine Test Stand } & 36^{\circ} 49.95^{\prime} & 116^{\circ} 18.50^{\prime} & 1158 & \text { SPZ } & 0.1 \mathrm{~K} \\ \text { LSM } & \text { Little Skull Mountain } & 36^{\circ} 44.32^{\prime} & 116^{\circ} 16.68^{\prime} & 1146 & \text { SPZ } & 220 \mathrm{~K} \\ \text { LVW } & \text { Las Vegas (West) } & 36^{\circ} 10.20^{\prime} & 115^{\circ} 11.25^{\prime} & .654 & \text { SPZ } & 3.3 \mathrm{~K} \\ \text { MCV } & \text { Mercury } & 36^{\circ} 38.01^{\prime} & 115^{\circ} 59.99^{\prime} & 1158 & \text { SPZ } & 100 \mathrm{~K} \\ \text { PRN } & \text { Pahroc Range } & 37^{\circ} 26.50^{\prime} & 115^{\circ} 04.00^{\prime} & 1524 & \text { SPZ } & 105 \mathrm{~K} \\ \text { SMN } & \text { Sleeping Mountain } & 37^{\circ} 08.60^{\prime} & 116^{\circ} 46.00^{\prime} & 1246 & \text { SPZ } & 25 \mathrm{~K} \\ \text { TSV } & \text { Twin Springs } & 38^{\circ} 12.10^{\prime} & 116^{\circ} 10.50^{\prime} & 1585 & \text { SPZ } & 105 \mathrm{~K}\end{array}$

\section{SANDIA LABORATORIES STATIONS}

$\left.\begin{array}{llllll}\text { BMN } & \text { Battle Mountain } & 40^{\circ} 25.90^{\prime} & 11^{\circ} 13.30^{\prime} & 1524 & \text { SPZ } \\ \text { DAC } & \text { Darwin, California } & 36^{\circ} 16.62^{\prime} & 117^{\circ} 35.62^{\prime} & 1432 & \text { SPZ } \\ \text { ELY } & \text { Ely } & 39^{\circ} 07.88^{\prime} & 114^{\circ} 53.52^{\prime} & 20.12 & \text { SPZ } \\ \text { LEE } & \text { Leeds, Utah } & 37^{\circ} 14.58^{\prime} & 113^{\circ} 22.60^{\prime} & 1067 & \text { SPZ } \\ \text { NEL } & \text { Nelson } & 35^{\circ} 42.74^{\prime} & 114^{\circ} 50.61^{\prime} & 1052 & \text { SPZ } \\ \text { TPI } & \text { Tonopah } & 38^{\circ} 04.29^{\prime} & 117^{\circ} 13.21^{\prime} & 1890 & \text { SPZ }\end{array}\right\}$ Variable

U. S. GEOLOGICAL SURVEY, YUCCA FLATS NEVADA STATIONS

NYC Charley

NYJ Joshua Tree

NYM Climax Mine

NYR Receiver Site

NYS

NYV Vern

$\left.\begin{array}{llll}37^{\circ} 09.30^{\prime} . & 116^{\circ} 09.32^{\prime} & 1574 & \text { SPZ } \\ 37^{\circ} 00.48^{\prime} & 115^{\circ} 58.48^{\prime} & 1195 & \text { SPZ } \\ 37^{\circ} 13.88^{\prime} & 116^{\circ} 03.14^{\prime} & 1489 & \text { SPZ } \\ 37^{\circ} 03.32^{\prime} & 116^{\circ} 05.50^{\prime} & 1188 & \text { SPZ } \\ 37^{\circ} 01.95^{\prime} & 116^{\circ} 10.13^{\prime} & 1402 & \text { SPZ } \\ 37^{\circ} 06.77^{\prime} & 115^{\circ} 59.40^{\prime} & 1340 & \text { SPZ }\end{array}\right\} \begin{gathered}1000 \mathrm{~K} \\ (20 \mathrm{X} \text { Viewer })\end{gathered}$

* Location in Nevada, unless otherwise specified. 
Administration/Earth Sciences Laboratories (NOAA/ESL), Las Vegas, Nevada. The Hypocenter Summary (appendix) is the result of programming only data from the Nevada network to compute earthquake locations.

\section{DISCUSSION}

The principal objective of the monthly report is to distribute preliminary seismic data acquired from the Southern Nevada Network of Seismograph Stations. A more comprehensive bi-annual seismicity report similar to Bayer (1972), is planned for publication at a later time.

Recorded arrival times and amplitudes are scaled in Las Vegas. Periodically, the properly formatted data are keypunched at the Las Vegas office and run through a local earthquake program described by Bolt, et al (1964), using a three-layer model. In order to obtain a hypocenter solution with the local station program, P-phase arrival times from at least three stations and one S-phase arrival time for a given earthquake mus $t$ be present. This compilation is preliminary and may be subject to later revision on the basis of current research.

The individual station readings, from which the hypocenter summary has been derived, are available upon request from the ESL Nevada Special Projects Party, 3060 South Highland Drive, Las Vegas, Nevada 89109 . The phase times are also sent to the National Earthquake Information Center (NEIC), Boulder, Colorado, on punch cards in the NEIC format. The area monitored by the NSPP (for hypocenter locations), is from 35 to 39 degrees north and 113 to 119 degrees west (see fig. 1). Seismic body wave phases from earthquakes which fall in the regional and teleseismic range are also scaled and mailed to the NEIC. 
In the Hypocenter Summary a " $D$ " following the depth indicates it is a fixed depth solution obtained by choosing the 5 kilometer depth interval that optimized the travel time residuals and standard error. An " $F$ " following the depth indicates the computer found a convergent solution in seven or less iterations by permitting the depth to move freely.

\section{GENERAL SEISMICITY}

Earthquakes recorded in the southern Nevada region during the month of August 1972, were more frequent than in the previous month; particularly in the Twin Springs, Nevada area, and on the Nevada Test Site. A total of 70 earthquakes were located by the NSPP. All earthquakes plotted on the seismicity map (fig. 2) occurred within the earth's crust $(\leq 30 \mathrm{~km})$. A preliminary evaluation of magnitudes suggests the great majority of the located events were microearthquakes $(1.0 \leq M \leq 3.0)$.

Southern Nevada, Twin Springs Area. Seismic activity continued in the Kawich Range, some $20 \mathrm{~km}$ southwest of the Twin Springs seismic station. Additional activity occurred approximately $20 \mathrm{~km}$ northeast of the station along the east flank of the Pancake Range.

The north Pahroc Range, northeast of Hiko Junction, had renewed activity. The south Pahroc Range also had several small earthquakes east and southeast of Station PRN (Alamo area).

As indicated on figure 3 , the Nevada Test Site and adjacent areas were unusually active during the month. There were 14 earthquakes located on the Test Site and 5 


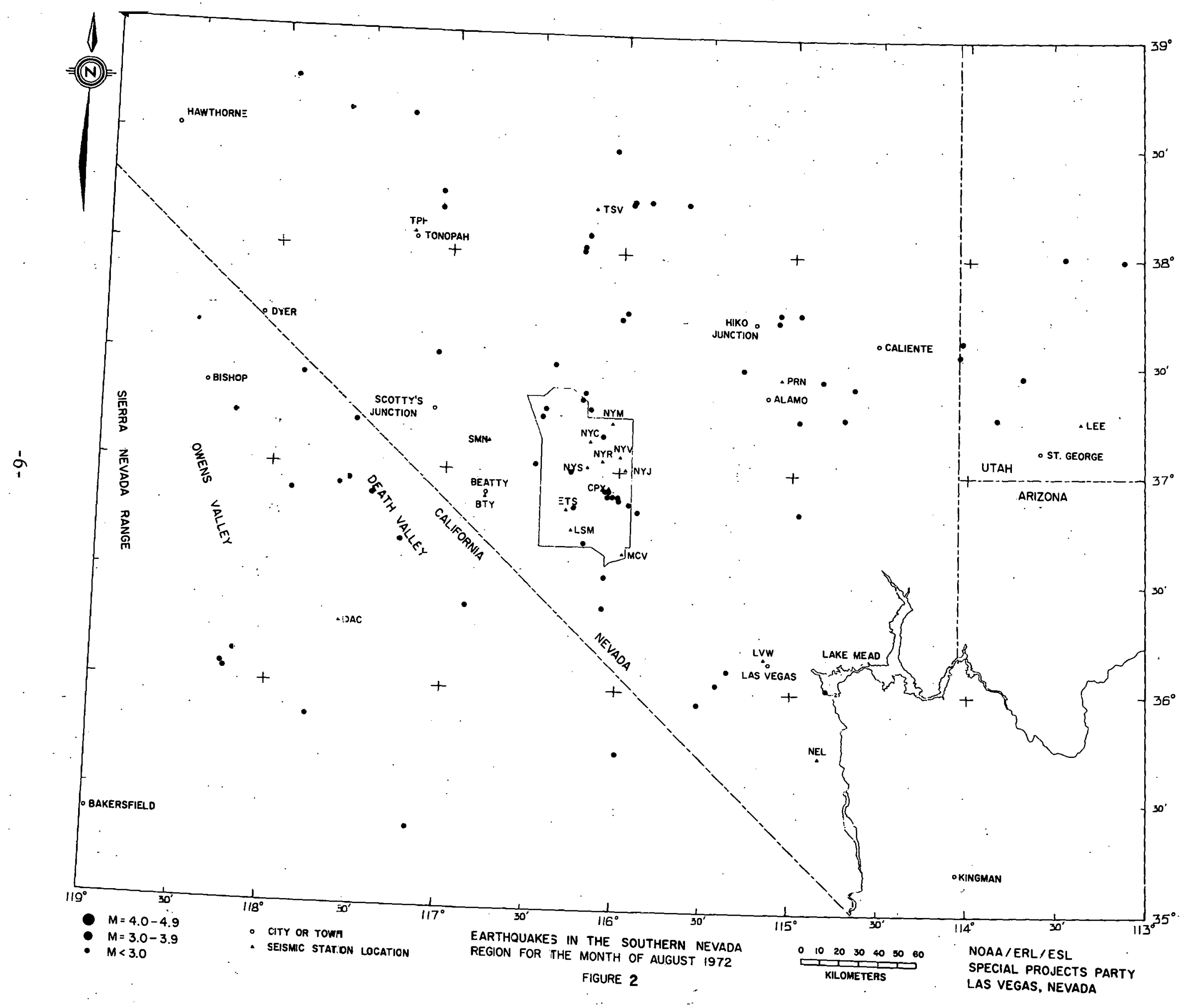




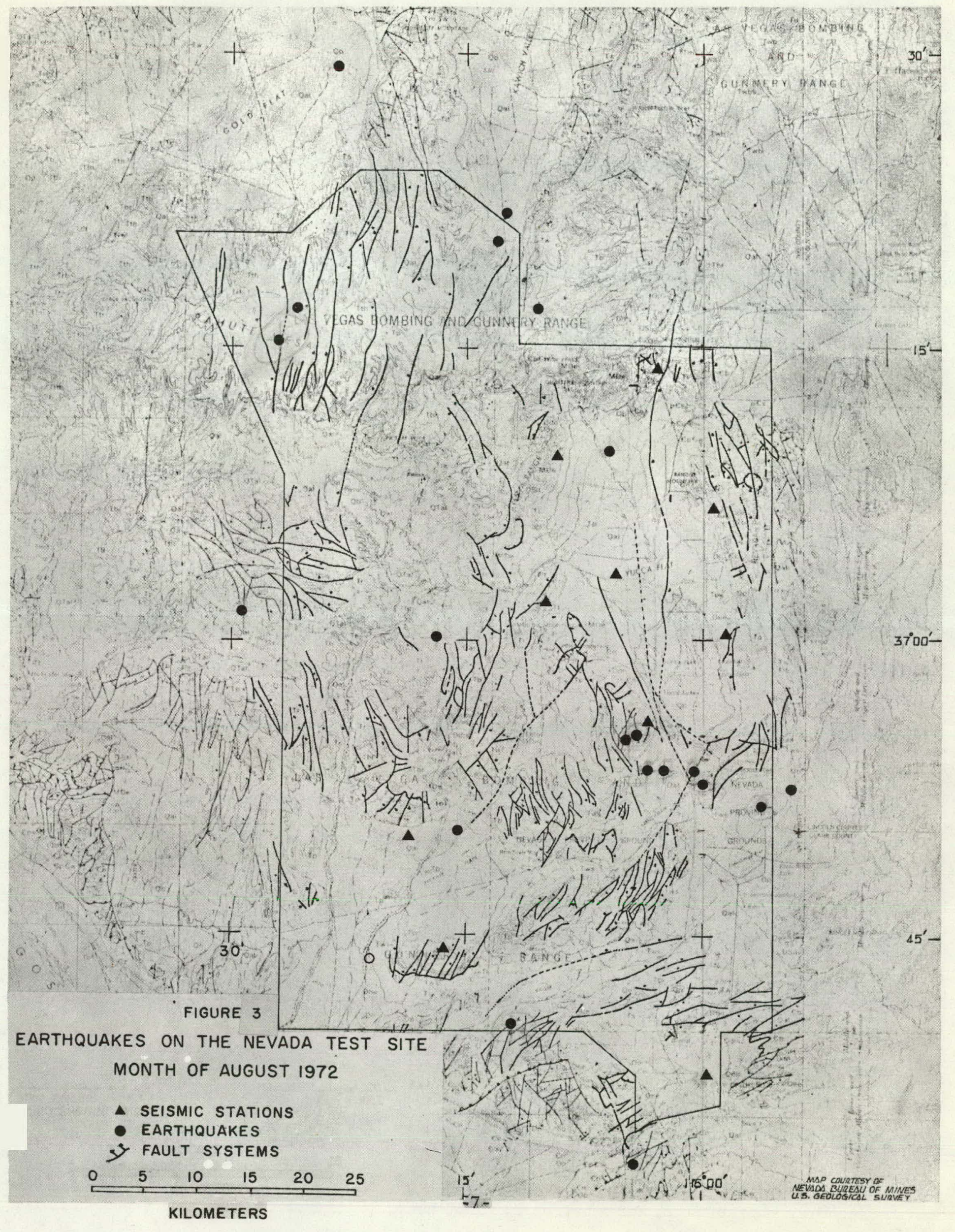


additional immediately adjacent to the Test Site. Of the 19 quakes, two occurred on Pahute Mesa (Area 20) and may have been the result of fault movement. Three small earthquakes occurred in the Belted Range at the north central perimeter of the Test Site. The most significant activities were the 8 earthquakes located from southwest to southeast of Station CPX. Six of the 8 quakes were recorded on the same day (August 23), and in an approximate time frame of 15 hours. These activities may be the result of minor strain release along the north-south trending Yucca Fault and accompanying branch faults near the lower (south) end of the fault system. The remainder of the earthquakes.were apparently random events on and adjacent to the NTS.

Three earthquakes were located in the Spring Mountains, southwest of Las Vegas toward the California border.

The remainder of the Nevada region was quiescent, particularly the Hoover DamLake Mead area, with only one located earthquake, approximately $10 \mathrm{~km}$ northwest of Hưver Dam.

Southeast California. The Owens Valley area was not particularly active during August. On the lower extremity of Owens Valley (Rose Valley), three earthquakes were recorded in the Sierra Nevada mountains west of Rose Valley. The other zone of interest for the month was in the Cottonwood Mountains, along the west flank of Death Valley, where four earthquakes were located.

Southwest Utah. Seismic activity continued in the Bull Valley Mountain area in the southwest corner of Utah. Four earthquakes were recorded from this area. Additionally, two earthquakes we re located west of Parowan Valley. 
A crustal model research project is underway in an attempt to obtain an idealized velocity/depth model for the southern Nevada seismic region. Future seismicity reports will reflect the outcome of this study.

There were no announced tests by the Atomic Energy Commission (AEC) in the southern Nevada region during the month of August 1972.

\section{ACKNOWLEDGMENTS}

The entire staff of the Nevada Special Projects Party participated in the operation and coordination of the NOAA/ESL seismograph network. Without the cooperation of the Sandia Laboratories and the U. S. Geological Survey, a large portion of the data that went into this report would not be available. The authors express grateful acknowledgment to Stanley R. Brockman for the computer processing, and to Thomas W. Bice for data plotting.

The operation of all the seismograph stations and the interpretations of the data from these stations are made possible through the financial support of the Nevada Operations Office of the United States Atomic Energy Commission (NVO/AEC), under Contract AT(29-2)-746,

\section{REFERENCES}

Bayer, K. C. (1972), Selsmicity of the southern Nevada region, December 22, 1971 to July 1,1972 , NVO-746-3, July.

Bayer, K. C. (1972), A preliminary seismicity study of the southern Nevada region for the month of July 1972, NVO-746-4, September.

Bolt, B. A., and T. Turcotte (1964), Computer location of local earthquakes within the Berkeley selsmograph network, computers in the minerel industries, Stanford University, 561. 


\section{A PPENDIX}

HY POCENTER SUMMARY 
A PPENDIX

HY POCENTER SUMMARY

\begin{tabular}{|c|c|c|c|c|c|c|c|c|c|}
\hline $\begin{array}{c}\text { August } \\
1972 \\
\end{array}$ & & $\begin{array}{l}\text { Origin Time } \\
\text { GMT }\end{array}$ & $\begin{array}{c}\text { Latitude } \\
\text { North }\end{array}$ & $\begin{array}{l}\text { Longitude } \\
\text { West } \\
\end{array}$ & & $\begin{array}{c}\text { Depth* } \\
(\mathrm{km})\end{array}$ & $\begin{array}{c}\text { Geographic } \\
\text { Area } \\
\end{array}$ & & \\
\hline 01 & & 051659.70 & $36.94^{\circ}$ & $117.55^{\circ}$ & & $08.8 \mathrm{~F}$ & Dry Mtn. & & \\
\hline 01 & & 224009.18 & 36.02 . & 114.81 & : : & $00.0 \mathrm{D}$ & Hoover Dam & & \\
\hline 02 & & $0028 \cdot 36.32$ & 36.03 & 115.42 & . & $00.0 \mathrm{~F}$ & Las Vegas & & \\
\hline 03 & & 010852.92 & 37.33. & 116.22 & & $00.0 \mathrm{~F}$ & Silent Canyon & & \\
\hline 03 & & 071916.59 & 36.89 & 116.06 & & $00.0 \mathrm{~F}$ & Lathrop Wells & ' & \\
\hline 03 & & 094212.93 & 36.91 & 117.49 & & $15.5 \mathrm{~F}$ & Tin Mtn. & . & \\
\hline 03 & & 114924.44 & 37.22 & 118.22 & & $15.0 \mathrm{D}$ & Blanco Mtn. & & \\
\hline 03 & & 153405.54 & 36.84 & 116.26 & & $00.0 \mathrm{~F}$ & Lathrop Wells & & \\
\hline 03 & & 205249.41 & 37.41 & 117.84 & & $25.0 \mathrm{D}$ & Magruder Mtn. & & \\
\hline 04 & & 124443.21 & 35.26 & 117.17 & & $10.0 \mathrm{D}$ & Opal Mtn. & & \\
\hline 04 & & 141724.42 & 37.43 & 114.84 & & $10.0 \mathrm{D}$ & Delamar Mts. & & $\because$ \\
\hline 04 & & 185952.75 & 36.89 & 116.04 & & $00.0 \mathrm{~F}$ & Lathrop Wells. & & \\
\hline 04 & & 204425.65 & 37.73 & 115.08 & & $00.0 \mathrm{~F}$ & Hiko & . & \\
\hline 04 & & 215006.09 & $36: 10$ & 115.37 & & $00.0 \mathrm{D}$ & Las Vegas & & \\
\hline 04 & & 232007.70 & 38.79 & $1.17,6.3$ & & $1.5 .0 \mathrm{D}$ & Paradise Peak & & \\
\hline 05 & & 0005.59 .49 & 35.70 & 115.99 & & $10.0 \mathrm{D}$ & Clark Mtn. & & \\
\hline 05 & & 111548.78 & 37.99 & 113.16 & & $10.0 \mathrm{D}$ & Cedar City & & \\
\hline 05 & & 123713.35 & 36.52 & 116.08 & & $25.0 \mathrm{D}$ & Lathrop Wells & & \\
\hline 07 & & 042106.81 & 38.02 & 116.23 & & $00.0 \mathrm{~F}$ & Warm Springs & & \\
\hline
\end{tabular}




\section{A PPENDIX \\ HYPOCENTER SUMMARY \\ (cont'd)}

\begin{tabular}{|c|c|c|c|c|c|}
\hline $\begin{array}{l}\text { August } \\
1972 \\
\end{array}$ & $\begin{array}{l}\text { Origin Time } \\
\text { GMT }\end{array}$ & $\begin{array}{l}\text { Latitude } \\
\text { North }\end{array}$ & $\begin{array}{c}\text { Longitude } \\
\text { West }\end{array}$ & $\begin{array}{l}\begin{array}{l}\text { Depth* } \\
(\mathrm{km})\end{array} \\
\end{array}$ & $\begin{array}{c}\text { Geographic } \\
\text { Area }\end{array}$ \\
\hline 08 & 062335.46 & $37.00^{\circ}$ & $116.28^{\circ}$ & $00.0 \mathrm{~F}$ & Silent Cạnyon \\
\hline 09 & $15 \quad 3931.37$ & 37.46 & 113.70 & $00.0 \mathrm{D}$ & St. George \\
\hline 09 & 202552.95 & 35.86 & 117.76 & $20.0 \mathrm{D}$ & Little Lake \\
\hline 11 & $1148 \quad 32.98$ & 38.01 & 116.23 & $00.0 \mathrm{D}$ & Warm Springs \\
\hline 13 & $\begin{array}{llll}05 & 34 & 12.62\end{array}$ & 37.70 & 115.09 & $19.6 \mathrm{~F}$ & Hiko \\
\hline 13 & 090751.79 & 38.62 & 117.25 & $15.0 \mathrm{D}$ & Toiyabe Dome \\
\hline 13 & 140139.30 & 37.40 & 114.66 & $18.0 \mathrm{~F}$ & Delamar Mts. \\
\hline 13 & $1652 \quad 17.43$ & 37.56 & 114.05 & $00.0 \mathrm{D}$ & Ely Range \\
\hline 13 & 201340.58 & 36.91 & 116.08 & $00.0 \mathrm{D}$ & Lathrop Wells \\
\hline 14 & 075945.76 & 37.20 & 117.54 & $15.0 \mathrm{D}$ & Magruder Mtn. \\
\hline 14 & 180125.85 & 37.25 & 114.97 & $12.7 \mathrm{~F}$ & Delamar Mts. \\
\hline 15 & 033642.10 & 37.70 & 116.01 & $00.0 \mathrm{D}$ & Quartzite Mtn \\
\hline 15 & $07 \quad 1251.34$ & 38.77 & 117.96 & 20.0.D & Paradise Peak \\
\hline 15 & 182851.75 & 37.48 & 115.29 & $00.0 \mathrm{~F}$ & Alamo \\
\hline 16 & 024034.23 & 36.37 & 116.13 & $00.0 \mathrm{D}$ & Ash Meadows \\
\hline 16 & $06 \quad 1756.17$ & 37.25 & 116.45 & $00.0 \mathrm{~F}$ & Silent Canyon \\
\hline 16 & 111301.81 & 38.01 & 113.45 & $10.0 \mathrm{D}$ & Milford \\
\hline 16 & 193424.69 & 37.52 & 117.07 & $05.0 \mathrm{D}$ & Goldfield \\
\hline 19 & 033230.98 & 38.26 & 117.07 & $25.0 \mathrm{D}$ & Tonopah \\
\hline 19 & 102807.86 & 37.02 & 116.49 & $25.0 \mathrm{D}$ & Silent Canyon \\
\hline
\end{tabular}


AP PENDIX

HY POCENTER SUMMARY

(cont'd)

\begin{tabular}{|c|c|c|c|c|c|}
\hline $\begin{array}{l}\text { August } \\
1972 \\
\end{array}$ & $\begin{array}{l}\text { Origin Time } \\
\text { GMT }\end{array}$ & $\begin{array}{l}\text { Latitude } \\
\text { North }\end{array}$ & $\begin{array}{c}\text { Longitude } \\
\text { West }\end{array}$ & Depth* & $\begin{array}{l}\text { Geographic } \\
\text { Area }\end{array}$ \\
\hline 19 & $15 \quad 1349.83$ & $37.26^{\circ}$ & $114.71^{\circ}$ & $00.0 \mathrm{~F}$ & Delamar Mts. \\
\hline 19 & 201200.79 & 35.95 & 115.53 & $15.0 \mathrm{D}$ & Clark Mtn. \\
\hline 19 & 230151.99 & 36.89 & 117.88 & $07.2 \mathrm{~F}$ & Dry Mtn. \\
\hline 20 & 012034.84 & 36.67 & 116.20 & $20.0 \mathrm{D}$ & Lathrop Wells \\
\hline 22 & $02 \quad 1456.21$ & 38.47 & 116.05 & $00.0 \mathrm{~F}$ & Warm Springs \\
\hline 22 & 105807.99 & 38.19 & 117.07 & $25.0 \mathrm{D}$ & Tonopah \\
\hline 22 & 121944.85 & 37.28 & 116.18 & $20.0 \mathrm{D}$ & Silent Canyon \\
\hline 22 & $1350 \quad 18.28$ & 37.62 & 114.04 & $04.9 \mathrm{~F}$ & Ely Range \\
\hline 23 & 080630.61 & 36.88 & 116.00 & $00.0 \mathrm{~F}$ & Mercury \\
\hline 23 & $0858 \quad 43.35$ & 36.92 & 116.07 & $00.0 \mathrm{D}$ & Lathrop Wells \\
\hline 23 & 105622.18 & 36.86 & 115.94 & $10.0 \mathrm{D}$ & Mercury \\
\hline 23 & 123652.15 & 36.88 & 115.99 & $00.0 \mathrm{~F}$ & Mercury \\
\hline 23 & 205933.37 & 36.89 & 116.01 & $15.0 \mathrm{D}$ & Lathrop Wells \\
\hline 23 & 232052.30 & 36.82 & 115.90 & $15.0 \mathrm{D}$ & Mercury \\
\hline 24 & 022004.40 & 37.73 & 114.97 & $16.9 \mathrm{~F}$ & Highland Peak \\
\hline 24 & 182057.60 & 36.06 & 118.25 & $00.0 \mathrm{D}$ & Kern Peak \\
\hline 24 & 182235.65 & 36.05 & 118.24 & $00.0 \mathrm{D}$ & Kern Peak \\
\hline 24 & 1823.41 .16 & 36.13 & 118.19 & $10.0 \mathrm{D}$ & Kern Peak \\
\hline 25 & 032832.78 & 37.16 & 116.10 & $00.0 \mathrm{~F}$ & Silent Canyon \\
\hline
\end{tabular}


A P PENDIX

HYPOCENTER SUMMARY

(cont'd)

\begin{tabular}{|c|c|c|c|c|c|c|}
\hline $\begin{array}{l}\text { August } \\
1972\end{array}$ & $\begin{array}{l}\text { Origin Time } \\
\text { GMT }\end{array}$ & $\begin{array}{l}\text { Latitude } \\
\text { North. }\end{array}$ & $\begin{array}{l}\text { Longitude } \\
\text { West }\end{array}$ & $\begin{array}{l}\text { Depth * } \\
(\mathrm{km})\end{array}$ & $\begin{array}{l}\text { Geographic } \\
\text { Area }\end{array}$ & \\
\hline 25 & 10.0402 .26 & $36.90^{\circ}$ & $116.04^{\circ}$ & $00.0 \mathrm{~F}$ & Lathrop Wells & \\
\hline 25 & 230924.01 & 38.08 & 116.20 & $20.0 \mathrm{D}$ & Warm Springs & \\
\hline 26 & 000207.45 & 37.36 & 116.21 & $00.0 \mathrm{~F}$ & Silent Canyon & \\
\hline 26 & 044111.55 & 37.28 & 116.43 & $00.0 \mathrm{D}$ & Silent Canyon & \\
\hline 27 & $\begin{array}{lll}11 & 17 & 10.80\end{array}$ & 38.20 & 115.85 & $25.0 \mathrm{D}$ & Troy Canyon & \\
\hline 27 & 113102.71 & 38.23 & 115.94 & $05.0 \mathrm{D}$ & Troy Canyon & \\
\hline 27 & 172329.66 & 38.23 & 115.94 & $00.0 \mathrm{~F}$ & Troy Canyon & \\
\hline 28 & 233604.20 & 37.26 & 113.85 & $10.2 \mathrm{~F}$ & St. George & \\
\hline 29 & $\begin{array}{lll}04 & 15 & 15.47\end{array}$ & 36.37 & 116.87 & $00.0 \mathrm{~F}$ & Furnace Creek & \\
\hline 29 & 044122.69 & 36.66 & 117.25 & $15.0 \mathrm{D}$ & Tin Mtn. & \\
\hline 31 & 112330.57 & 37.49 & 116.39 & $00.0 \mathrm{D}$ & Silent Canyon & \\
\hline 31 & 213637.92 & 36.87 & 117.42 & $16.4 \mathrm{~F}$ & Tin Mtn. & \\
\hline
\end{tabular}

\footnotetext{
* $\mathrm{D}=$ Fixed Depth Solution $\mathrm{F}=$ Free Depth Solution
} 
Distribution:

Nevada Operations Office, U. S. Atomic Energy Commission, Las Vegas, Nevada

Douthett, E. M.

Halstead, P. N。

Kinnaman, R. L.

Loux, R. R.

Technical Library (3)

NVOO Pancl of Consultants

Bustad, L. K. , University of California, Davis, California 95616

Deere, D. U., 2552 S. W. 14th Dr., Gainsville, Florida 36201

Jacobsen, L。 So, 267 Belgreen Place, Oakmont, Santa Rosa, California 95405

Kisslinger, C. , University of Colorado, Boulder, Colorado 80302

Lintz, J., University of Nevada, Reno, Nevada 89507

Newmark, N. M., University of Illinois, Urbana, Illinois 61801

Schultz, V., Washington State University, Pullman, Wa shington 99163

Thompson, T. F., 713 Crossway Road, Burlingame, California 94010

Van Dorn, W. G., Scripps Institute of Oceanogra phy, La Jolla, California 92037

Von Lossberg, L. G., Sheppard T. Powell \& Associates, Baltimore, Maryland 21201

Wilson, J. T., University of Michigan, Ann Arbor, Michigan 48105

Wilson, S. D., Shannon \& Wilson, Inc., 1105 N. 38th St., Seattle, Washington 98103

Witherspoon, T. A., University of California, Berkeley, California 91109

National Oceanic \& Atmospheric Administration, ERL/ESL

Algermissen, S. T., Boulder, Colorado 80302

Alldredge, L. R., Boulder, Colorado 80302

Jordan, J. N., Boulder, Colorado 80302

Lander, J. F., NEIC, Boulder, Colorado 80302

Matthiesen, R. B., San Francisco, California 94105

Mickey, W. V., Boulder, Colorado 80302

Murphy, L. Mo, Boulder, Colorado 80302

Tocher, D., San Francisco, California 94105 (2)

Von Hake, C. , EDS D/62/S, 1135 Broadway, Colorado 80302 
Distribution (cont'd)

Advanced Research Projects Agency, Arlingt on, Virginia 20301

Lukasik, S. J.

AFTAC/VELA Seismological Center, Alexandria, Virginia 22314

Pilotte, F. F.

Air Force Office, Scientific Research, Arlington, Virginia 22209

Best, W. J.

Blume, John A. and Associates Engineers, San Francisco, California 94105

Blume, John A. and Associates Research Division, Las Vegas, Nevada 89109

California Institute of Technology, Pasadena, California 91109

Allen, C. R.

Anderson, D.

Nordquist, J.

CER, Geonuclear Corporation, Las Vegas, Nevada 89114

Alcock; E. D.

Colorado School of Mines, Golden, Colorado 80401

Major, M. W.

Romig, P.

Simon, Ruth B.

Cormell University, Ithaca, New York 14850

Oliver, J.

Defense Nuclear Agency, Test Command, Kirtland AFB, Albuquerque, New Mexico

Grote B.

Environmental Research Corporation, Las Veg as, Nevada 89102

Hays, W. W. (2) 
Distribution (cont'd)

Lamont Doherty Geological Observatory, Palisades, New York 10964

Sykes, L.

Lawrence-Livermore Laboratory, Livermore, California 94551

Carothers, P. C.

Coyle, P. E.

Germain, L. S.

Hadley, J. W.

Rodean, H. C.

Technical Information Library

Los Alamos Scientific Laboratory, Los Alamos, New Mexico 87544

Ogle, W. E. (3)

Massachusetts Institute of Technology, Cambridge, Massachusetts 02139

Aki, K.

Toksoz, M. N.

Medearis, Kenneth \& Associates, Ft. Collins, Colorado 80521

Medearis, K.

Sandia Laboratories, Albuquerque, New Mexico 87115

Banister, J. R.

Ellett, D. M.

Merritt, $M_{0}: L$.

Sandia Technical Libraries (2)

Tendall, D. M.

Weart, W. E.

St. Louis University, St. Louis, Missouri 63103

Stauder, W. J.

Technical Information Center, U. S. Atomic Energy Commission,

Oak Ridge, Tennessee 37830 (2) 
Distribution (cont'd)

University of California, Berkeley, California 91109

Bolt, B.

Cloud, W. K.

University of Nevada, Reno, Nevada 89507

Ryall, A.

University of Utah, Salt Lake City, Utah 84112

Cook, K. L.

University of Wisconsin, Milwaukee, Wisconsin 53201

Willis, D. C.

U. S. Atomic Energy Commission, Washington, D. C. 20545

Biles, M. B. (DOS)

Camm, Major Gen. Frank A., Hq. (DMA) (3)

Hamburger, R. (DAT)

U. S. Geulugical Survey, Menlo Park, Caltfornia 94025 .

Healy, J. (2) 